\title{
Trip Quality, Tourist Satisfaction, and Behavioral Intention on The New Tourism Destination: A Case Study in Pabangbon Panoramic Hill, West Java
}

\author{
Rina Suprina* Devita Gantina \\ Trisakti School of Tourism, Jl. IKPN Tanah Kusir, Bintaro, Jakarta, Indonesia
}

\begin{abstract}
When the new tourist destination occurs, people usually come because of their curiosity. The purpose of this study was to analyze Trip Quality, Tourist Satisfaction, and Behavioral Intention of those who visited Bukit Panorama Pabangbon (Pabangbon Panoramic Hill) as a new tourism destination in Bogor district, West Java, Indonesia. The research method was descriptive quantitative. This research was a survey using a questionnaire. In the initial stages, validity and reliability tests were carried out, and the test results show that all items in the questionnaire were valid and reliable. The questionnaire was then distributed to respondents using a simple random sampling technique resulting 100 sets of data. Then the mean score of each variable and correlation value was calculated. The results showed that in general, the tourists' trip quality was good in which the affordable ticket got the highest score, while local transportation got the lowest. On the whole, they were satisfied with their experience visiting the site, and they were willing to return and recommend this new tourist attraction to friends and relatives. Among the construct under study, the correlation between trip quality and behavioral intention was stronger than the correlation between tourist satisfaction and behavioral intention. All are positive correlations.
\end{abstract}

Keywords: Trip Quality, Tourist Satisfaction; Behavioral Intention

DOI: $10.7176 / \mathrm{JTHS} / 52-05$

Publication date: December $31^{\text {st }} 2020$

\section{Introduction}

Tourism is one of the important sectors in Indonesia that can help the economy of a region if it is developed well by the government and surrounding communities (Bimantara, 2019). The tourism industry is a unique combination of various factors so that the operational planning of a destination is different from other economic sectors. A tourist destination has many relationships with diverse stakeholders, with different goals and requirements. A tourism destination is always different in size, attractiveness, and benefits offered to tourists., but how to attract tourists to revisit or recommend a destination to others is complicated for the success of destination development. Good tourism management should enable tourists to enjoy tourism activities and benefit the welfare of local communities (Pitana and Diarta, 2009: 81).

Nowadays, with the extensive use of social media, many instagrammable tourism attractions occur, especially the attractions that explore beautiful scenery (Triandini and Yusrini 2018). One of the new tourist destinations is Panorama Pabangbon, located in Bogor District, West Java, Indonesia. This tourist destination provides a beautiful panoramic view for those who like nature and mountain view. This destination also fits for those who like photography because there are many beautiful and interesting spots to capture. However, beautiful scenery and interesting photo spots only cannot guarantee that tourists who come to this destination will be satisfied and willing to revisit or recommend the site to others.

As noted by Chen, Lee, Chen and Huang (2011), it is important to explore tourist satisfaction with the destination as well as the service quality, which are associated with tourist behavioral intention. According to Backman \& Veldkamp, 1995 in Chen (2006: 2) "The tourist behavior includes the choice of a destination to visit and subsequent evaluations and future behavioral intention. The subsequent evaluations include the travel experience or perceived trip quality during the stay, perceived value and overall satisfaction, while the future behavioral intention includes the intention to revisit and the willingness to recommend. There has been a great body of studies focusing on the interrelationship between quality, satisfaction, and behavioral intention". By understanding the relationship between future behavioral intentions and their determinants, tourism and destination managers will better know how to build an attractive image and market their efforts to maximize the use of available resources.

In general, the success of tour operators relies on their ability to fulfill customer wants. From the viewpoint of demand, enticing the tourists to revisit and recommend the destination to others are main aspects of successful tourism destination development (Chen \& Tsai, 2007). In order to succeed in the present competitive business environment, tourism operators need to be aware of patterns and dynamics in tourist demand. A better understanding of relationships between tourists' future behavioral intentions and its antecedents allow tourism operators to optimize customer satisfaction and improve marketing efforts (Perera and Vlosky 2013).

This paper seeks to provide a more comprehensive insight into the factors that make up tourists' future 
behavioral intentions. By understanding the relationship between the critical elements for tourism destination development, the tourism organization managers would make better and more effective decisions with more efficient use of resources. Therefore, this study aims to examine the role of trip quality and tourist satisfaction in predicting future behavioral intentions of tourists in Pabangbon panoramic hill, the new tourism destination in Bogor District, West Java, Indonesia.

\section{Literature Review}

\subsection{Trip Quality}

Chen \& Sai (2006: 2) elaborated that "Trip quality is the visitor's assessment of the standard of the service delivery process in association with the trip experience." The above definition states that trip quality is a standard rating of tourists for services received and then compares with previous travel experiences or travel experiences at other similar destinations.

Furthermore, Chen 2006 in Buhalis (2000: 2) explains that the measurement of trip quality includes four aspects, namely: (1) Hospitality: the quality of the trip assessed from the elements of hospitality and the quality of service received by tourists, (2) the environment: the quality of the trip assessed on the elements of the environment enjoyed by tourists during the trip, (3) transportation: The quality of the trip assessed by the ease of reaching the destination location and (4) the amenities: the quality of the trip assessed over other supporting aspects so as to perfect the trip and trip to be of high quality and meaningful. text text text text text text text text text text text text text text text text text text text text text text

\subsection{Tourist Satisfaction}

Satisfaction is a psychological term containing a sense of well-being and a pleasure arising from achieving what one wants and expects from a desirable good and/or service (Chi \& $\mathrm{Qu}, 2008)$. Consumer satisfaction is generally described as a post-consumption appraisal of a particular good or service. It results from a customer's view of the value obtained (Rojas, 2010; Vazifehdoost et al. 2014). Customer satisfaction is an individual situation linked to a person's feeling of pleasure or disappointment (Martin et al., 2008). Furthermore, Kirillova and Udalova (2013) explain that satisfaction is created by comparing the customer's expectations before and after consumption. It expresses the emotional and subjective state of the consumer linked to their needs. Tourist satisfaction is considered a significant factor in keeping the tourism industry competitive because it impacts the choice of destination and the purchase of goods and services (Kozak \& Rimmington, 2000).

\subsection{Behavioral Intention}

From the view of leisure and recreation, behavioral intention is the intention of visitors to revisit within a year and their willingness to travel often to the destination (Baker \& Crompton, 2000). Further factors involved in evaluating behavioral intention include the willingness to recommend to others and positive word-of-mouth (Bigne, Sanchez, \& Sanchez, 2001). The revisit intention of visitors to a destination may be influenced by their performances at the destination, the promotional efforts, and the spreading news of new attractions at the destination (Aziz et al., 2012). The concept of revisit intention originates from behavioral intention ( $\mathrm{Wu}, \mathrm{Li}, \& \mathrm{Li}$, 2018), which furthermore roots from consumer behavior. Consumer behavior is the study of the mechanisms involved in purchasing, consuming, using or discontinuing goods, programs, concepts, or interactions to fulfill the customer's needs and desires (Tuten and Solomon, 2017).

\section{Research Methodology}

Research methods used in this study was descriptive quantitative to determine the relationship among trip quality, tourist satisfaction and behavioral intention. Participants in the study were visitors who had ever visited Pabangbon Panoramic Hill. Data was collected using a questionnaire, interview, observation, and literature study. The questionnaire was designed on a five point Likert-type scale ranging from 1 (strongly disagree) to 4 (strongly agree). A validity and reliability test was conducted on the questionnaire. Then the questionnaire was distributed online and offline. One hundred completed questionnaires were retrieved for analysis. Data analysis included descriptive analysis, correlation analysis, and regression analysis using SPSS 20 Software. 


\section{Result and Discussion}

Table 1. Mean Value of Trip Quality

\begin{tabular}{lcc}
\hline Statement & Mean Value & Category \\
\hline Affordable tourist attraction ticket price. & 3.257 & Very high \\
Good food and drinks at the tourist attraction. & 2.986 & high \\
Good service at the tourist attraction. & 3.203 & high \\
Affordable food and beverage & 3.068 & high \\
You feel safe when you are in the tourist destination & 3.095 & high \\
The cleanliness of tourist attractions is good. & 3.014 & high \\
Accessibility is good. & 3.027 & high \\
Good local transportation. & 2.716 & high \\
Adequate parking facilities & 3.041 & high \\
Sufficient travel information. & 2.959 & high \\
Clear signage to reach the destination. & 3.027 & high \\
\hline
\end{tabular}

Table 1 gives the results of calculating the level of trip quality during respondents' visit to Pabangbon. The measurement was based on the mean scores on a Likert scale from 1 to 4 (strongly disagree to strongly agree). The results show that overall trip quality is good, with a mean value is 3.036. The highest mean score is an affordable tourist attraction ticket price, which has a very high category, and the lowest one is local transportation. Even though local transportation has the lowest mean value, it is still included in the high category.

Table 2. Mean Value of Tourist Satisfaction

\begin{tabular}{ccc}
\hline Indicator & Mean Value & Category \\
\hline $\begin{array}{l}\text { Overall you are satisfied with Pabangbon Panoramic Hill because } \\
\text { the reality you received meets your expectations. }\end{array}$ & 3.095 & high \\
\hline
\end{tabular}

Tourist satisfaction questionnaire results are reported in Table 2. From the mean score of respondents' answers based on Likert scale from1 to 4, it shows the mean score was 3.095 with a high category and indicated approval. Then it concluded that visitors were satisfied with their visit to Pabangbon Panoramic Hill.

Table 3. Mean Value of Behavioral Intention

\begin{tabular}{lcc}
\hline Indicator & Mean Value & Category \\
\hline $\begin{array}{l}\text { Willingness to come back to Pabangbon Panoramic Hill in the } \\
\text { future. }\end{array}$ & high \\
\hline $\begin{array}{l}\text { Willingness to recommend Pabangbon Panoramic Hill to friends } \\
\text { and relatives }\end{array}$ & 3.108 & high
\end{tabular}

Table 3 presents the data of respondents' answers regarding behavior intention. It shows a mean of 3.041 and 3.108 with a high category. This means that the respondent in this study mostly had a tendency to revisit Pabangbon in the future and be willing to recommend Pabangbon to their friends and relatives.

In order to examine the relationship between variables, Pearson's correlation test was administered. The result showed a positive strong correlation between trip quality and behavioral intention with a correlation value of 0.612 . Meanwhile, the correlation between tourist satisfaction and behavioral intention (intentions of recommendation and repeat visits) was positive moderate with correlation value of 0.419 . Therefore, the correlation between trip quality and behavioral intention was stronger than the correlation between customer satisfaction and behavioral intention.

This positive relationship can be interpreted as satisfied tourists tend to have good behavioral intentions to revisit or return to the same destination after enjoying a good trip quality. The finding supports the previous research that suggests satisfaction has positive and direct relationships with intentions of recommendation and repeat visits (Chen et al. 2011).

Statistical tests were conducted to find the effect of trip quality and tourist satisfaction toward behavioral intention. The R-Square value was 0.382, which means Behavior Intention is influenced by the trip quality and tourist satisfaction for $38.2 \%$. The rest is explained by other variables that are not examined in this study. F test was conducted to see the simultaneous effect of independent variable toward dependent variable. The significance value was 0.00 , lower than the alpha value of 0.05 . Therefore, trip quality and tourist satisfaction gave a simultaneous effect on behavior intention. T test was calculated to see the partial effect of trip quality and tourist satisfaction towards behavioral intention. The result in Table 5 showed that the significance of trip quality was 0.00 , lower than alpha of 0.05 . It means trip quality significantly affected behavioral intention. Meanwhile, tourist satisfaction did not give significant effect on behavioral intention because the significance value was higher than $0.05(0.38)$ This finding is line with the previous study which shows that trip quality tends to highly influence future behavioral intention. Trip quality is of special importance to predict tourists' intention to revisit and 
recommend the destination (Perera and Vlosky 2013). However, the result contradicts the findings of Chen and Tsai (2007) who reported insignificant effect of trip quality on behavioral intentions.

\section{Conclusion}

In general, the quality of the trip experienced by tourists visiting the Pabangbon Panoramic Hill has a good value, with the highest value being the affordable ticket to tourist attraction. The lowest mean value is local transportation. The tourists' satisfaction is generally good, and in general they want to come back and recommend Pabangbon Panoramic Hill to their friends and relatives. In this study, the relationships among trip quality, tourist satisfaction, and behavioral intention were also examined. The result showed a significant simultaneous effect of trip quality and tourist satisfaction on behavioral intention. Meanwhile, partially trip quality affects behavioral intention, but tourist satisfaction did not significantly affect behavioral intention.

In order to increase tourist's willingness to revisit, there are some things to be done, such as creating new attractions besides existing photo spots so tourists can get a different experience. Another important factor is providing local transportation from the main road to the location of the attraction so that these attractions are easier to reach. Finally, increase marketing through social media or conduct events to attract more tourists.

\section{References}

Armani, W., Rahyuda, K., Giantari, I. G. A. K., \& Sukaatmadja, I. P. G. (2019). Customer Satisfaction and Behavioral Intentions in Tourism: A Literature Review. International Journal of Applied Business and International Management, 4(3), 84-93.

Aziz, N. A., Ariffin, A. A. M., Osmar, N. A., \& Evin, C. (2012). Examining the impact of visitors' emotions and perceived quality towards satisfaction and revisit intention to theme parks. Jurnal Pengurusan, 35, 97-109.

Baker, D. A., \& Crompton, J. L. (2000). Quality, satisfaction and behavioral intentions. Annals of tourism research, 27(3), 785-804.

Bigne, J. E., Sanchez, M. I., \& Sanchez, J. (2001). Tourism image, evaluation variables and after purchase behaviour: inter-relationship. Tourism management, 22(6), 607-616.

Bimantara, P., Pratama, P. D. A., \& Wismanjaya, K. A. (2019, November). How Culture Resources Developed As A New Tourism Destination In Buleleng Regency. In International Conference on Tourism, Economics, Accounting, Management, and Social Science (TEAMS 19). Atlantis Press.

Buhalis, D. D. (2000). Marketing the competitive destination of the future. Tourism Management, 21(1), 97-116.

Chen, F.C, \& Tsai, D.C.,(2007). How destination image and Evaluative factors affect behavioral intentions?. Tourism Management. 28(7), 1115-1122

Chen, C. M., Lee, H. T., Chen, S. H., \& Huang, T. H. (2011). Tourist behavioural intentions in relation to service quality and customer satisfaction in Kinmen National Park, Taiwan. International Journal of Tourism Research, 13(5), 416-432.

Chi, C.G. and Qu, H. (2008) 'Examining the Structural Relationship of Destination Image Tourist Satisfaction and Destination Loyalty: An Integrated Approach', Tourism Management, $29: 624-636$.

Jerkins,O.H., (1999). Understanding and Measuring Tourist Destination Images. International Journal of Tourism Researchch. 2. 1-15

Kirillova, K.. and Udalova, I. (2013) 'Modern Marketing: Choice Between Traditional Marketing and Marketing of Relationship', Economy and entrepreneurship, 12 (3) : 687-689.

Kozak, M., \& Rimmington, M. (2000). Tourist satisfaction with Mallorca, Spain, as an off-season holiday destination. Journal of Travel Research, 38(3), 260-269. https://doi.org/10.1177/004728750003800308

Lee, C., Lee, Y., \& Lee, B. (2005). Korea's destination image formed by the 2002 world cup. Annals of Tourism Research, 32(4), 839-858.

Martin, D., O'Neill, M., Hubbard, S., \& Palmer A. (2008). The Role of Emotion in Explaining Consumer Satisfaction and Future Behavioral Intention. Journal of Services Marketing, 12, ; 224-236.

O’Leary. S., \& Deegan. J., (2003). People. Pace, Place : Qualitative and Quantitative iamges of ireland as a tourism destination in Franch. Journal of vacation Marketing. 9(3). 213-226

Perera, P., \& Vlosky, R. (2013). How Previous Visits Shape Trip Quality, Perceived Value, Satisfaction, and Future Behavioral Intentions: The Case of Forest-Based Ecotourism in Sri Lanka. International Journal of Sport Management, Recreation \& Tourism, 11.

Pitana, I. G., \& Diarta, I. K. S. (2009). Introduction to tourism. Jogjakarta: Andi Offset.

Rojas, M. (2010) 'Intra-Household Arrangements and Economic Satisfaction', Journal of Happiness Studies, $11(2): 225-241$.

Ryan, C. (2002). From motivation to assessment. In C. Ryan (Ed.), The tourist experience (2nd ed., pp. 58-77). London: Continuum.

Sugiono.2011. Metode penelitian kuantitatif, kualitatif dan R\&D. Bandung: Alfabeta

Triandini, R \& Yusrini, L. (2019). Pengaruh Lokasi Dan Fasilitas Terhadap Kepuasan Pengunjung Di Panorama 
Pabangbon Leuwiliang Bogor. Akpindo eRepository, 3(1).

Tuten, T. L., \& Solomon, M. R. (2017). Social media marketing. Sage.

Vazifehdoost, H., Rahnama, A. and Mousavian, S.J. (2014) 'Evaluation of the Impact of Brand Purchase Involvement, Satisfaction, Experience and Brand Trust on Loyalty to Brand', Mediterranean Journal of Social Sciences, 5(20): 30-54.

Widoyoko, E. P. (2014). Teknik Penyusunan Instrumen Penelitian. Yogyakarta: Pustaka Pelajar.

Wu, H.-C., Li, M.-Y., \& Li, T. (2018). A study of experiential quality, experiential value, experiential satisfaction, theme park image, and revisit intention. Journal of Hospitality \& Tourism Research, 42(1), 26-73. 